DOI: 10.2478/eurodl-2014-0031

\title{
LEARNING INNOVATION: A FRAMEWORK FOR TRANSFORMATION
}

\author{
GillySalmon [gilly.salmon@uwa.edu.au],The University of Western Australia, Australia
}

\begin{abstract}
Learning with and through technological enhancements operates in a landscape unrecognisable only a few years ago. Focussing on Higher Education, this article shows how to capture and model complex strategic processes that will move the potential of online and blended learning in universities to new stages of development. It offers the example of a four quadrant model created as a framework for an online and blended learning innovation strategy, and its successful implementation in practice.
\end{abstract}

Keywords: higher education and change, incremental and radical innovation, learning innovation, successful implementation, quadrants

\section{Context}

"A surprising number of innovations fail not because of some fatal technological flaw or because the market isn't ready... most often the very skills that propel an organization to succeed in sustaining circumstances systematically bungle the best ideas for disruptive growth" (Christensen \& Raynor, 2013, Chapter 7, para. 1).

Almost every Higher Education (HE) institution throughout the world is trying to accommodate new ways of learning, using digital and Web technologies, and at the same time meeting students' shifting aspirations, needs and expectations. The pace of innovation for learning and teaching is speeding up in the face of disruptive and constructive forces which are creeping into HE, challenging traditional ways of thinking and doing (Christensen \& Horn, 2013; Miller et al., 2014).

The adoption of emerging technologies and innovation in learning and teaching offers wonderful opportunities, but also outstrips HE's ability to exploit appropriate pedagogical and systematic approaches (Hrabowski, 2011). Highly complex changes involve considerable individual and institutional change, beyond the provision of technology (Salmon \& Angood, 2013; Zentel et al., 2004). To understand and undertake the rethinking and associated organisational changes, the natural intrinsic conservatism in universities must be surfaced, explored and addressed (Weller \& Anderson, 2013; Westera, 2004). The challenge is to promote growth and improve learning experiences and outcomes. Recently, an opportunity has been presented to the world-wide sector to 'catch' disruptive waves: MOOCs (Massive Online Open Courses) attracted attention and pointed to alternative ways of thinking and acting for learning design and reaching new students (Daniel, 2012; Grimmelmann, 2014; Liyanagunawardena et al., 2013).

Change has been a constant through HE and indeed throughout the last 50 years (Barber et al., 2013; Herbst, 2013; Morgan, 2013; Barber \& Rizvi, 2013). However a high level of resilience is needed in order to transform; especially the ability to change and to overcome 'natural' resistance whilst maintaining purpose, function and sustainability (Hopkins, 2009; Weller \& Anderson, 2013). 
It was at various points during the first decade of the $21^{\text {st }}$ Century that the widespread adoption of easy-to-use learning technologies, such as Virtual Learning Environments (VLE, sometimes called Learning Management systems, LMS), were mistaken for educational innovation (Westera, 2004). Many projects, authors and managers in HE institutions saw digitally-enhanced learning as offering high potential for business development and quality improvement, and subscribed to the prediction that the teaching paradigm would somehow change. However, by the second decade of the century, it was recognised that the digital revolution was impacting rather more slowly on HE than other sectors. Many claim that progress has been slow and incremental rather than 'revolutionary' (Bokor, 2012; Fallon, 2013; Keohane, 2013).

The drivers of innovation in education and its associated development are complex. There is passionate intent to improve quality and equity, and to avoid false dichotomies between the two aspirations (Colbert, 2013; Crow, 2013). There is typically a desire to reach more learners at lower cost, as well as to education them better. The competitive business environments drive higher standards with the students' experiences as priorities (Chow, 2013; Mulgan, 2013).

\section{Strategic framework for digitally enhanced learning and pedagogical innovation}

As learning technologies increasingly became deployed in HE, the price of hardware and connectivity fell. Fast, reliable mobile networks are now common. Since the advent of Information, Communications and Technology (ICT) for learning, there have been many people working at all levels from policy to practice on transformation. However, there is a lack of institutional learning from the many thousands of isolated experiments and innovations as, in many universities, internal investment, reward, recognition and approval systems do not encourage systematic change or experimentation (Allen et al., 2012; Calvert, 2005; Schneckenberg, 2009). The previous overselling and exaggerated claims from commercial providers led many academics to focus on the explicit attributes of a learning technology rather than the inherent pedagogical assumptions, their intrinsic potential and their value for the development and achievement of new ideas, missions, markets and improvements in quality. Further, as a wide range of mobile devices and social media became available to consumers, it became clear that these could 'transfer' to educational adoption.

Learning technologies are not transparent - their properties are not obvious and they do not broadcast their utility. No VLE will ever be enough in itself to create great digitally-enhanced learning. However, teachers and designers frequently attribute the capacity for doing or achieving the learning to the technology. It just cannot be successful without appropriate, well-supported and focused human intervention, good learning design or pedagogical input and the sensitive handling of the process over time by trained online tutors. There is a slowly increasing move to understanding that the future for learning needs to be created through design, rather than exhorting academics to teach better (Laurillard, 2012) The complexity is further increased by the impact of ICT occurring at differing intervention points - from the 'micro' level such as animations in teaching materials, to the 'meso' level, such as changes to library facilities or provision of media centres, to the 'macro' policy and large-scale collaborations, sometimes across private-public boundaries (Zentel et al., 2004).

\section{Strategy for innovation in Higher Education}

In the right circumstances, even the most traditional institutions can drive transformational change. Innovation in technology is much more likely to happen, and a preferred and desired future created if the various stakeholders collaborate to bring about change (Olivier et al., 2013). Goals and missions need to be clear. 'Front line' staff (especially faculty members) need support to provide the solutions to new challenges rather than be seen as the barriers to change (Cruz, 2013). There are well-rehearsed intentions and plans to achieve economic and quality benefits European Journal of Open, Distance and e-Learning - Vol. 17 / No. 2 
from the introduction of online and blended learning - and many HE institutions have been seduced by this potential, in part because of their competitive and demanding market places.

\section{Strategic framework for digitally enhanced learning and pedagogical innovation}

Any pedagogical innovation has start-up costs, especially if associated with the sharing and reusability of resources and processes. Costs associated with digitally-enhanced learning include the capital and direct costs of the technology itself. In universities much of the infrastructure is now sunk costs. However, the major investment comes from the development of resources, involving a number of professionals, and considerable academic and technical staff development, to increase the chances of success of an innovation. In the medium term, the costs associated with human resources are likely to be higher, but offer more potential and quality than the technology provision (Zemsky \& Massy, 2004; Bates \& Sangra, 2013). The costs of digital resources attract much more attention and challenge than the investment in more conventional learning infrastructure, such as lecture theatres. On campus costs are often in legacy systems and buildings. Attempting scaling-up of digitally-enhanced learning through 'hand crafting' cannot be supported over time. Therefore, predictions need to be made of which courses are worth funding in this way, and serious choices must be made and resources diverted in those directions. As yet, there's a dearth of information about cost analysis of online education in comparison to face-toface education, and yet the search for financial benefit continues (Carey \& Trick, 2013, p.20).

While digitally-enhanced learning in $\mathrm{HE}$ is now considered (indeed, welcomed by many staff) for its potential, real development beyond projects initiated by innovators has so far been modest. Most educational institutions are still struggling to engage a significant percentage of students and staff in digital learning (Hixon et al., 2012). All universities are vulnerable to a wide variety of internal and external drivers, but typically have a high resistance to meaningful organisational change. They are awash with rich resources in the form of intelligent keen individuals who are rarely appropriately directed to pedagogical innovation, nor sufficiently self-motivated to radically transform their teaching.

Digital learning, whether combined with other forms of learning and teaching or not, is multifaceted and involves shifts both in understanding and behaviours (Gregory \& Salmon, 2013; Salmon \& Wright, 2014). Many academics responsible for both the curriculum and the pedagogical processes arising from the digital innovation have not made these shifts.

In order to enable sustainability in the digital learning age, the scaling-up and embedding of innovation into institutional management strategy is fundamental (Christensen et al., 2011; Edgecombe et al., 2013). Human dimensions of innovation, such as staff development for online teaching and effective fast learning design, need to shift focus from the previously dominant training of the technological tool, to the practical and pedagogy aspects affecting the use of the technology (Salmon \& Wright, 2014).

Note that evidence is important (Mulgan, 2013). Digital technologies make the use of data for direct and fast feedback in efficacy of learning processes (Iwata, 2013). Those that attempt research within their teaching find that generalizing and model building is all but impossible from highly individual studies with multiple variables. It is realistic to recognise that implementing digitally-enhanced learning is a hugely complex undertaking with multiple contexts and stakeholders - and risks (Pittard, 2004). 


\section{Learning design}

Individuals and small groups, such as departments in universities, have their own desires, abilities, histories and preferred artefacts - in other words, they are closely situated. Universities themselves consist of cultural, historical, institutional and power-constructed contexts (Salmon \& Angood, 2013).

The early focus on technological infrastructure has given way to increased awareness and dialogue on learning design, connectedness and in blending newer and older approaches to learning (Jaipal Jamani \& Figg, 2013). The design of learning activities and the links between online and common tasks in teaching have become much more important (Salmon, 2013a), however such knowledge is of no value if it cannot be used in a flexible and contextualised manner, and in particular be embedded into the everyday teaching processes of a university.

The taste for looking beyond the next year in terms of learning, and hence being able to develop staff and resources for medium-term futures, has been tainted by a lack of evidence, and some expensive crashes. Some of the failures have a high profile - such as the UK e-University demise - but most happen quietly and painfully within individual institutions (Whitworth, 2012).

There is considerable evidence that digital learning in the $21^{\text {st }}$ Century has become much more concerned with macro analysis, value for money, incorporation and integration of multimedia, blended learning and adherence to standards and benchmarking. There is little evidence however of emergence of harvesting, transferring and testing the sturdiest models and principles. Essentially, while online learning is no longer a novelty, it is now facing the same problems that conventional $\mathrm{HE}$ institutions have faced for many years - quality assurance, assessment and the exchange of excellent forward-looking practice. Because of its innovative approach, missionary zeal and army of challengers and sceptics, digitally-enhanced learning healthily faced these issues head on, early on in its history.

\section{Introducing digitally-enhanced learning successfully}

Although new modes of learning with technologies and their role as drivers of innovation figure in the aspirations of most policy makers and senior executives, many institutions are still struggling to engage a significant percentage of students and staff in development beyond 'projects'. Research is currently not providing answers to this problem and more models are needed to demonstrate the transferability and scalability of learning innovation. The technology is more than robust enough for attention to turn to business development and pedagogical innovation and away from technical 'solutions' and 'fixes'.

There are two main ways in which digitally-enhanced learning can be introduced into traditional teaching, whether on campus or at a distance. One is through large-scale centralization and provision of professional services. The second is more incremental, perhaps a little slower and more challenging, but gradually involving all members of staff to make their contribution, particularly with a design focus (Laurillard, 2012; Salmon et al., in press). This involves the choice of easy-to-use technologies and investment in personal and departmental learning and development. The latter has the advantages of developing capacities for the longer term and keeping 'ownership' with the academics and their departments. 


\section{Strategic underpinnings to a digitally-enhanced learning strategy}

We can distinguish between a moderate change strategy and a more radical approach (Basir et al., 2010; Johnston et al., 2001; Norman \& Verganti, 2014; Ritala \& Hurmelinna-Laukkanen, 2013; Whitworth, 2012). An incremental approach involves enhancing existing practice through introducing well-rehearsed and easy-to-use learning technologies.

At the same time, a research agenda that brings forward weaker signals from the learning technology's environment, and indeed society's, suggests a more challenging approach to changes in the use of learning technologies and the associated pedagogy. This more radical approach ultimately impacts on organisational structures - a more risky but transformational approach. We need to find a way that the two approaches are not mutually exclusive, and can be turned into practical actions within HE institutions.

A further dimension of a strategic framework for HE is to distinguish between core technologies and peripheral learning activities (Salmon, 2005). The core forms the basis of current activities that must be maintained, and since effort and investment have been put into them, they do not present a high risk. We could consider the use of university provided Learning Management Systems (LMS/VLE), and the e-resources provided by a university library, to be core technologies. Nearly all universities have adapted to using LMS/VLE and their add-ons, so these core capabilities will no longer be innovative.

Peripheral technology is 'on the edge' and offers more choice. A range of potential new and adaptive technologies need therefore to be included in the strategy. These can be different from the LMS/VLE, incorporated into them, or be an extension of them. Some peripheral technologies do become mainstream over time, so the strategy needs ways of including potential new technologies and preparing for new capabilities. Hence, it is also important to focus on building increased capacity and capability for digitally-enhanced learning innovation, and on continually looking ahead to potential and new learning technologies and their applications related to a mission or objective.

One word of caution regarding how these concepts apply to the introduction of educational technologies in HE institutions: the core capabilities that are obvious or are most enjoyed or admired within a university may not be strategically relevant. Instead they need to be those that a wide range of 'stakeholders' (students, clients, partners, funding bodies) both perceive and value.

The pace of technological change shortens the lifespan of most technology-based resources, but, as discussed, all universities demonstrate exceptional slowness to transform. When a particular technology or platform is adopted, for example Blackboard, it is very difficult to change later. Key capabilities, however, have the potential to be more durable than the technological resources on which they are based.

Innovative capacity promotes the transfer of knowledge (see Bell \& Bell, 2005 and Winslett, 2012 for a brief review of relevant models of innovation). For example, some universities are good not only at developing, but also utilising and transferring their research.

Collaborations and alliances with others, or consortia and joint projects, offer ways to explore innovation and peripheral technologies at somewhat lower risk. Each technological development must be placed in its context and culture. Each individual institution has a need to develop digitally-enhanced learning to match its own culture, but within an overall context of common development needs with other HE institutions (Garcia, 2004). 
Most universities see themselves as 'knowledge sharing' entities. Many now have 'openness' as a value, at least for research outcomes and some for Massive Open Online Courses (MOOCs). Sharing what works for incremental innovation such as improving quality, approaches to student retention and achievement and teaching with technology are often topics for sector knowledge sharing, perhaps because they are often context-specific and difficult to fully imitate elsewhere. Evidence from other sectors suggests that pursuing radical, individualistic innovation leads to more novel solutions and more extensive new market opportunities (Norman \& Verganti, 2014).

\section{Strategic Framework}

The innovation framework that I use in my own change practice for digitally-enhanced learning strategies in universities is based on a resource-based definition (Pertusa-Ortega et al., 2010; Salaman \& Asch, 2003) of the match that a university can make between its internal resources, structures and skills, and the opportunities and risks created by its external environment. Such a framework both implies identifying an individual institution's core capabilities and existing strengths (what it is good at, what makes it special), and how a strategy can take advantage of these in a competitive world (what it can do well and differently). A strategy based on those kinds of strengths is likely to be more durable, and harder to imitate than 'off-the-shelf strategies (Hamel \& Valikangas, 2003), or those based on traditional contingency or market-led approaches (Pertusa-Ortega et al., 2010; Salaman \& Asch, 2003).Thus, choices of where to be innovative and where to increase the development of digitally-enhanced learning should not be based on a bland view of market, but on a more complex view of the value of digitally-enhanced learning meeting the university's mission and objectives as well as playing to its distinguishing institutional strengths (Richards et al., 2004).

\section{Transformative framework for learning innovation}

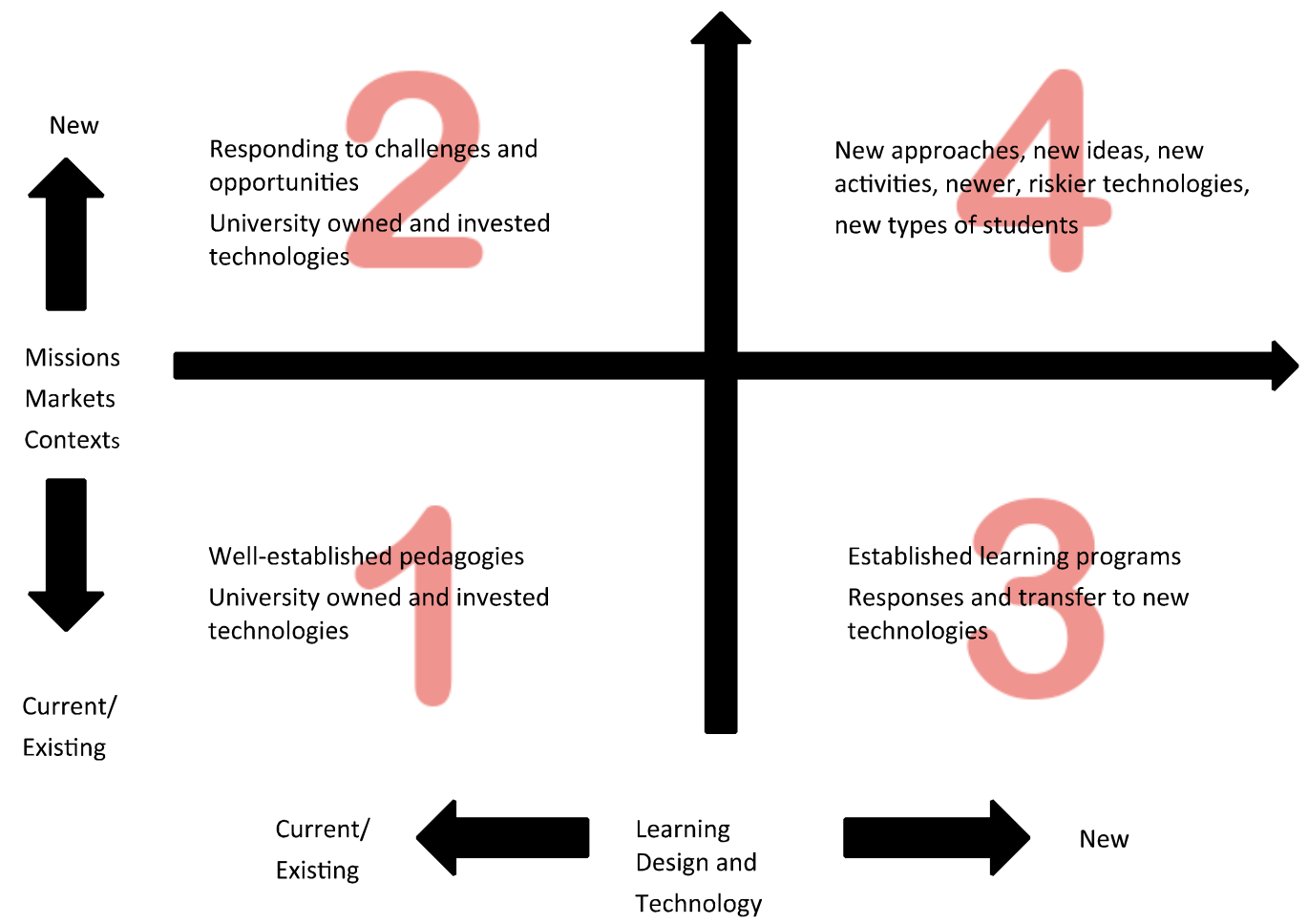

Figure 1. Transformative Framework for Learning Innovation 


\section{Summary}

- Quadrants Figure 1 represents the deployment of a university's existing core capabilities and capacity through incremental innovation. Quadrant 1 suggests deploying the understanding of technologies already in place in the institution to solve problems and increase the quality of learning. Improved learning design, professional development and staff support are needed, but despite this investment, reasonably low risk. Time scale: 1-2 to implement years. Timescale - ongoing - continuous.

- Quadrant 2 suggests a different approach to incremental innovation, taking the core strengths and incremental development from Quadrant 1 into new missions and markets - more organisational development is needed. Some risk is present in where to put investments and choices of partners. Time scale: typically 1 year + .

- Quadrant 3 suggests deployment of a university's key strengths in learning and teaching but with adjustments to new technologies, many of them cannot be owned by the university. These involve some risk since more imagination and prototyping are involved. Time scale to implement: 1-2 years.

- Quadrant 4 represents a more radical view of change using peripheral technologies, new products and new markets and missions. Higher risk but potentially higher value for those that succeed. Unlikely to happen without specific investment by the university in learning innovation. Time scale: 2-4 years.

\section{Quadrant 1}

The lower left-hand box of the matrix suggests achieving growth with established core technological products and processes, such as LMS/VLE and e-libraries, embedding them further into learning and teaching processes and using them for an increasing number of purposes and students. Here is the gradual evolution from campus to blend and/or traditional paper-based distance learning, to pedagogically sound digitally-enhanced learning.

Much can be achieved by deploying 'off the shelf technologies such as commercial LMS/VLE, but they require careful business planning, investment in staff development and support, and excellent provision of ICT within university systems. They also require astute planning of markets, missions, objectives, student requirements and resources for the support and development of the technology.

The university should first identify and target those areas where there is potential for growth, rapid improvement in quality or efficiency gains. The aim can be to move more of its regular learning into the digital environment but in such a way that will enable it to pilot scalable processes. For example, the focus could be to further develop communication and group teaching in the online environment, rather than from print to online resources. Content is rarely viewed as a major differentiator by potential students: value lies in brand, support, group teaching, peers and communication (Hart, 2012). Personalization and choice based on learning needs is the first step away from the limitations inherent in printed texts and face-to-face classrooms, and applies well as a mission for Quadrant 1. Here also lies the 'flipped classroom' (Mangan, 2013) and opportunities to rethink physical spaces (Gardner, 2013). The use of personal repositories, wikis, e-portfolios blogs etc. can be a system for managing and sharing both pedagogical and content knowledge, and can be driven from 'add-on' (often called 'building blocks') from the LMS/VLE - clearly making the most of the university's investment.

An aspiration for this quadrant could be to ensure that every student of a university, regardless of location or mode of learning, receives equivalent services and learning experiences. Another could be to transform assessment as much as learning and teaching. Whilst these developments 
are valuable and directly impact on students' learning, they rarely reposition the institution for the future or form a true differentiation.

\section{Quadrant 2}

The upper left-hand box (existing pedagogies and technologies/new missions and markets) represents using learning technologies to address different and new markets, missions, levels and disciplines of learning and teaching, but using the core expertise and technologies already developed. Realistic approaches must be taken to the market to reduce risks as far as possible. As digitally-enhanced learning depends on volume, there should be a minimum contracted commitment before new technology-enhanced learning processes are developed. In this quadrant, marketing can take place in new countries or through new distribution channels with some confidence in the e-learning process.

In Quadrant 2, the university will be able to keep up with the increasing uptake of digitallyenhanced learning and offer acceptable online learning to students. The university will then be in a good position to expand into new locations and new types of courses, and respond to funding opportunities.

One key area in this quadrant is the move to recognise that learning does not need to include a face-to-face element. On campus learning can deliver blended courses, while entirely digital courses can exploit the best of network connectivity. There is a huge and whole range of emerging technologies (Johnson et al., 2013), from mobile devices, virtual worlds, augmented reality to 'The Cloud' (Harvard Magazine, 2012). This quadrant stimulates everyone to consider the exportation of learning and teaching through the reach that technology offers rather than the importation of more students to campus.

Removing the need to attend a campus at a particular place or time provides a greater degree of flexibility for learners' lifestyles previously unimagined and opens up the possibilities of new markets. The range of applications and educational resources are giving way to choices in technologies, innovative pedagogical design, and providing appropriate online human support. Entirely digital courses free the students and the university from physical infrastructures, and enable institutions to offer their best knowledge and research to market segments that would remain unattainable where campus attendance is required. The market and audience for entirely digital courses are quite different from those of campus based courses - not better, not worse, but a new approach. Fully digital learning offers exceptional opportunities for student-centred approaches to exploit learning technologies, markets, learning experiences and outcomes. Open access learning engages an even wider demographic of people desiring HE opportunities, including less advantaged sectors of the community, low socio economic status (SES) and longterm illnesses (Allen \& Seamen, 2013; Guri-Rosenbilt, 2013; Simpson, 2012; Watson et al., 2013).

\section{Example of Quadrant 2}

An example of successful innovation in this quadrant is Swinburne Online (Lipson, 2013; Mackenzie, 2013; Swinburne Online, 2014). Swinburne Online is a joint venture between Swinburne University and a commercial, publicly listed company called SEEK Limited. Swinburne Online has some unique features. First, it recruits students that require Swinburne University's entry requirements, assessment requirements and full quality standards. Second, it benefits from some jointly shared resources with the university such as a digital library and the LMS. It has developed an effective knowledge transfer processes from the university academics to Swinburne Online's learning designers, and a high touch, fully digital scaffolded learning process. It was extremely successful in recruiting large numbers of undergraduates on full degree courses without reducing the equivalent on-campus registrations. 


\section{Quadrant 3}

The lower right-hand quadrant (existing missions/new technologies) addresses the many new technologies available. Here are the opportunities to exploit widely used every-day technologies, including mobile devices such as tablets, smart phones, GPS applications and their associated and attractive applications (apps). Few of these have been developed specifically for learning, and need good understanding of potential teaching applications to be successful in new contexts. Then there is the uptake of social media of all kinds, many of which can be harnessed for learning purposes (see for example Chapter 4 of Salmon, 2013a). Additionally there are others that have been developed for learning such as Open Educational Resources (OERs) and Massive Open Online Courses (MOOCs).

The implications of wide-scale wireless networking together with extensive social media are that, because content and communication are available anywhere, learning is no longer tied to a particular location. As more standardised encoded and syndicated content delivery becomes readily available, there will be little, if any, limitation on the place or manner in which learning may be available. Many new technologies are appropriate for off-campus use, as combinations and blends, for dynamic delivery of content and for human intervention and support of remote learning. There are new understandings of the use of knowledge creation, sharing and repositories that can be deployed.

In this quadrant, small-scale prototypes need to be undertaken that focus on the changing nature of learning, rather than developing more and more technological features. The university can be confident in offering small-scale pilots with existing students and clients, with a view to developing appropriate digitally-enhanced learning pedagogy through evaluation, feedback and research. Staff development and new systems and processes are necessary for scaling-up of any successful new approaches by prototyping, and in this way, risk and investments are reduced.

\section{Quadrant 4}

The higher right-hand box (new/new) is the most challenging, risky but also potentially rewarding. Research and development projects about digitally-enhanced learning are being published that go beyond the simplistic 'what works' scenarios of stage one of technology introduction. A constant approach to working with the emerging future potential is required to capture the potential of new technologies and ideas. They need exploring and bringing together into usable principles and understandings along with appreciation of their transferability into teaching and innovation in a university. This quadrant offers the greatest potential to successfully put a university on the digitally-enhanced innovation in learning map. The university should allow new strategies to emerge to support an assessment of effective directions and the associated risks. Engagement with this quadrant will require the university to continually scan both the technology and marketing environment, and develop one or two innovative projects or seek several smaller ones. This is the quadrant to be a leader rather than a follower and almost certainly requires true partnerships across sectors

This area requires a new approach to 'looking over the horizon' and exploring those emerging technologies that may be enhanced or translated into use for learning - maybe wearable technology, augmented reality, gamification or 3D printing (McGonigal, 2011; New Media Consortium, 2014).

Quadrants 3 and 4 are what academics and inquiry-based teachers do best: chart the path, blaze the trail, experiment, adapt and adopt (Cruz, 2013). Let them loose on innovation in learning they know how to build collaborative teams, work across disciplines, share findings and advance knowledge. 
In Quadrant 4, and indeed in Quadrant 3, it is critically important that investment is made in replicating success and investing in the institutionalisation of initiatives, projects and pilots that are proving worthwhile (Cruz, 2013), and being smart enough to identify and to let go of those irrespective of good intentions - that are not.

Rethinking approaches to learning should also occur. There is little published literature explaining online learners in terms of student retention and academic outcomes (Beaudoin et al., 2009), and focusing specifically on learners from lower social economic backgrounds (Jaggars, 2011). While there is debate about online compared to on-campus environments, research has largely focussed on content and instructional design (Ferrão et al., 2009) rather than learning outcomes, or the mode in which the learning takes place (Tamim et al., 2011). The MOOC phenomenon has happened very quickly (Bady, 2013), leading to calls for research into impact and efficacy for learners and ways of adding value for institutions.

Implicit in the framework for learning innovation is an ongoing and continuous mechanism that feeds Quadrant one with consolidated, tested and appropriate initiatives from the other three quadrants thereby renewing and updating and reviving the operational context of the Now/Now quadrant.

\section{Framework for digitally-enhanced learning strategies - the example of Leicester}

The University of Leicester in the UK is typical of the traditional campus-based universities keen to capitalize on the benefits of digitally-enhanced learning, while also having to move from $20^{\text {th }}$ Century distance learning (print plus 'flying lecturers') to $21^{\text {st }}$ Century online learning for its largescale distance programs.

Late in 2004, I was charged with preparing a strategic framework for the development of digitally-enhanced learning at the University of Leicester (www.le.ac.uk). In a 'research-led' university, dominated by campus learning in traditional subjects, the process of strategy development needed to deeply engage management, staff, academics and support departments. The university had a history of postgraduate distance learning, mainly in overseas markets, as well as established staff development and support process for the use of learning technologies. The university recognised that digitally-enhanced learning needed to be further developed with appropriate pedagogical and customer-driven underpinnings. There was support from senior management and from a wide variety of staff. There was a need for a strategy to harness enthusiasm, focus the use of limited resources, and deploy practical knowledge whilst avoiding over-directive approaches. In researching and developing both a process and a framework for the strategy, I was strongly influenced in my thinking by my previous work on models of digitallyenhanced learning and staff development (for example, Salmon, 2011), as well as 16 years as a change management academic at the UK Open University.

My approach to engaging others in the university with the digitally-enhanced learning strategy directly addressed a number of key issues, outlined earlier in this chapter. I wished to ensure that the proposed strategic model took account of the following:

1. The role for research into innovative learning design and delivery;

2. The development of both core and peripheral learning technologies;

3. Realistic approaches to market development, both for online and blended learning; 
4. An embeddedness in the university's overall aspirations, identified mainly through its existing formal plans and strategies, but interpreted through formal and informal discussions;

5. The need to determine and make explicit the purpose of pedagogical innovation and the objectives of the scaling-up of digitally-enhanced learning;

6. The importance of preserving existing resources, projects and motivations across the university; and

7. The strategy was located within wider national frameworks and directions.

The framework I describe below was used for the university's first innovation strategy in 2005, and another updated innovation strategy in 2009, also using the quadrants. A wide range of implementation actions were agreed upon and implemented, including the 'Media Zoo' - a communication device to engage all members of the university in understanding the purposes and actions associated with the strategy, and serving as an innovations laboratory where engagement in research and development was encouraged for all members of the university community research and collaborators. The quadrant approach proved easy to explain, and successful in interesting and engaging academic and professional staff (Goolnik, 2012; Wheeler, 2009). Many of the original actions then became implemented in the university's core learning and teaching strategy and approaches, and the strategy proved flexible as more technologies and opportunities became available over the years.

The University of Leicester was awarded the title of 'University of the Year 2008-09' by Times Higher Education. The Times Good University Guide 2010 ranked Leicester $15^{\text {th }}$, and featured within the top 20 rankings for Leicester in the 2008-09 academic year by the Independent, The Sunday Times and the Guardian. In the 2008 National Student Survey, 92 per cent of full-time students taught at Leicester were satisfied with their programme. This is a level of satisfaction exceeded only by Cambridge among mainstream universities teaching full-time students in England. For a research-led university, it shows that innovation in learning and teaching was having a huge impact (Armellini et al., 2009; Salmon, 2005).

\section{Summary and conclusions}

At all levels there is confusion and choices on how innovation should be driven, and who should lead this (Selingo, 2013). The quadrant approach provides a sufficiently complex response offering the opportunity both for new missions and markets and the improvement of learning and teaching, whilst recognising the transformation potential of new technologies. Research demonstrates that organisations successfully innovate, survive and thrive because their core members are willing, even eager, to do things differently (Zemsky, 2013). The quadrant approach offers a way of engaging key core members - the academics and faculty - of HE along with their leaders in an achievable and acceptable innovation agenda. It addresses the notion that employing digital technology enables incrementally better ways of obtaining new goals for learning and teaching with technology. In addition, the strategy enables a more radical view towards further horizons and insists that some people and some resources should be targeted to the new. The aim is not a disruption of the intent of an institution, but instead a transformation to achieve more and better. 
In short, to achieve the kinds of innovations in learning and teaching, a multiple strategy approach is needed to include:

- Systemic innovations: High-level, accessible strategies addressing a variety of audiences and stakeholders, with a strong rigour and evidence base;

- Pedagogical innovations: Ways of addressing new approaches to learning design and engaging staff (Gregory \& Salmon 2013; Salmon \& Wright, 2014) leading to the achievement of excellent forward-looking and future-proofed practice to assist those involved in learning and teaching for entirely digital and/or open learning; and

- Reframing the concepts of open entry for learners and digitally-enhanced evidence-based transformations, together with ongoing future research, development, knowledge and revised practice.

Ultimately, innovation in HE is not about 'developing best practice' (which can be backward looking), but empowering better innovators within the context and structure of historical forms. I quote from Jose Cruz, Provost and Vice-President for Academic Affairs at California State University:
"Transformational change is grounded in a thorough understanding of an institution's mission and strategic context. It enhances what works and suppresses what doesn't in existing policies, practices and structures" (Cruz, 2013).

See also: Distance Education; Evolutionary Approach to Education Science; Computer-assisted Instruction; Educational Media; Instructional Design; Open Education: Learning and Teaching; Education, Economics of Environments for Education; ICT and Education; Educational Change; Educational Innovation; Educational Leadership; The Higher Education Market; Higher Education Management; HE Pedagogy.

\section{References}

1. Allen, E.; Seaman, J.; Lederman, D.; Jaschik, S. (2012). Conflicted: Faculty and online education, 2012. Babson Survey Research Group.

http://www.insidehighered.com/sites/default/server_files/files/IHE-BSRG-Conflict.pdf (accessed 21.12.14).

2. Allen, I.E. and Seaman, J. (2013). Changing course: Ten years of tracking online education in the United States. Babson Survey Research Group \& Quahog Research Group, LLC. San Francisco. http:/ / www.onlinelearningsurvey.com/reports/changingcourse.pdf (accessed 21.12.14).

3. Armellini, A.; Salmon, G.; Hawkridge, D. (2009). The Carpe Diem journey: Designing for learning and transformation. In T. Mayes, D. Morrison, H. Mellar, P. Bullen \& M. Oliver (eds.), Transforming Higher Education through technology-enhanced learning. The Higher Education Academy, York.

4. Bady, A. (2013). The MOOC moment and the end of reform. In Association of American Colleges and Universities, 99(4).

5. Barber, M. and Rizvi, S. (2013). Asking more: The path to efficacy. Pearson, London, England. http:/ / efficacy.pearson.com/wp-content/uploads/2013/11/Asking-More-The-Path-toEfficacy-high-res1.pdf

6. Barber, M.; Donnelly, K.; Rizvi, S. (2013). An avalanche is coming: Higher education and the revolution ahead. Institute for Public Policy Research, London, England.

http://www.ippr.org/publication/55/10432/an-avalanche-is-coming-higher-education-andthe-revolution-ahead (accessed 21.1214). 
7. Basir, H.M.; Ahmad, A.; Noor, N.L.M. (2010). Institutional strategy for effective blended elearning: HCI perspective of sustainable embedding. In the Proceedings of User Science and Engineering (i-USEr), 2010 International Conference, IEEE, (pp. 71-76).

8. Bates, A.W. and Sangra, A. (2013). Managing technology in Higher education: strategies for transforming. Wiley.

9. Beaudoin, M.F.; Kurtz, G.; Eden, S. (2009). Experiences and opinions of e-learners: What works, what are the challenges, and what competencies ensure successful online learning. In Interdisciplinary Journal of E-Learning and Learning Objects, 5(1), (pp. 275-289).

10. Bell, M. and Bell, W. (2005). It's installed ... now get on with it! Looking beyond the software to the cultural change. In British Journal of Educational Technology, 36(4), (pp. 643-656).

11. Bokor, J. (ed.) (2012). University of the Future: A thousand year old industry on the cusp of profound change. Ernst \& Young. http://www.ey.com/AU/en/Industries/Government---PublicSector/UOF_University-of-the-future (accessed 21.12.14).

12. Bonaccorsi, A.; Daraio, C.; Geuna, A. (2010). Universities in the new knowledge landscape: Tensions, challenges, Change - An introduction. In Minerva, 48(1), (pp. 1-4). doi:10.1007/s11024-010-9144-0

13. Brown, S. (2010). From VLEs to learning webs: The implications of Web 2.0 for learning and teaching. In Interactive Learning Environments, 18(1), (pp. 1-10). doi:10.1080/10494820802158983

14. Calvert, J. (2005). Distance education at the crossroad. In Distance Education, 26(2), (pp. 227238).

15. Carey, T. and Trick, D. (2013). How online learning affects productivity, cost and quality in bigher education: An environmental scan and review of the literature. Toronto, Canada: Higher Education Quality Council of Ontario.

http://www.heqco.ca/SiteCollectionDocuments/How_Online_Learning_Affects_Productivi ty-ENG.pdf (accessed 21.12. 14).

16. Chow, B. (2013). Deeper learning. . In M. Barber \& S. Rizvi (eds.), Asking more: The path to efficacy, (pp. 11-16). Pearson, London, England.

17. Christensen, C.M. and Horn, M.B. (2013). How disruption can help colleges thrive. In The Chronicle of Higher Education, October 4, (p. B30).

18. Christensen, C.M.; Horn, M.B.; Caldera, L.; Soares, L. (2011). Dismpting College: How Disruptive Innovation Can Deliver Quality and Affordability to Postsecondary Education. Center for American Progress, Innosight Institute. http:// eric.ed.gov/?id=ED535182.

19. Christensen, C.M. and Raynor, M.E. (2013). The innovator's solution: Creating and sustaining successful growth. Harvard Business School Press.

20. Colbert, V. (2013). Improving quality and equity in education. In M. Barber \& S. Rizvi (eds.), Asking more: The path to efficacy, (pp. 37-42). Pearson, London.

21. Crow, M.M. (2013). The new American university. In M. Barber \& S. Rizvi (eds.), Asking more: The path to efficacy, (pp. 49-53). Pearson: London.

22. Cruz, J.L. (2013). What are the barriers to innovation? In Forum discussion paper, The Chronicle of Higher Education, October 4, (p. B43).

23. Daniel, J. (2012). Making Sense of MOOCs: Musings in a maze of myth, paradox and possibility. In Journal of Interactive Media in Education, (pp. 1-20). 
24. Dutton, W.H.; Blank, G.; Groselj, D. (2013). Cultures of the internet: The internet in Britain. Oxford Internet Survey 2013. Oxford Internet Institute, University of Oxford.

25. Edgecombe, N.; Cormier, M.; Bickerstaff, S.; Barragan, N. (2013). Strengthening developmental education reforms: Evidence on Implementation efforts from the Scaling Innovation Project. CRCC Working Paper No. 61. http://www.scalinginnovation.org/wpcontent/uploads/2013/06/strengthening-developmental-education-reforms.pdf (accessed $21.12 .14)$.

26. Fallon, J. (2013). Preface. In M. Barber \& S. Rizvi (eds.), Asking more: The path to efficacy, (pp. 25). Pearson, London, England.

27. Ferrão, S.; Galván, R.; Rodrigues, S. (2009). E-knowledge, e-learning towards e-competence: The development of a model that illustrates the acquisition of competences on virtual learning environments. In the Proceedings of the European Conference on Intellectual Capital, (pp. 200-209).

28. Garcia, B.C. (2004). Digitally enhanced learning in a knowledge capital: the Manchester universities experience. In the Proceedings of the Online Educa Conference, Berlin (Berlin, ICWE), (pp. 426-431).

29. Gardner, L. (2013). Colleges adapt (slowly) to classrooms 2.0. In The Chronicle of Higher Education, October 4, (p. B22).

30. Goolnik, G. (2012). Change management strategies when undertaking elearning initiatives in higher education. In E Journal of Organizational Learning \& Leadership, 10(2), (pp. 16-28).

31. Gregory, J. and Salmon, G. (2013). Professional development for online university teaching. In Distance Education, 34, (pp. 256-270).

32. Grimmelmann, J. (2014). The Merchants of MOOCs. In Seton Hall Law Review, 44, University of Maryland Legal Studies Research Paper No. 2014-6. http:/ / ssrn.com/abstract=2358253 (accessed 21.12.14).

33. Guri-Rosenbilt, S. (2013). Open/distance teaching universities worldwide: Current challenges and future prospects. In EDUAKCJA, 2(4), (pp. 4-13).

http://wyrwidab.come.uw.edu.pl/ojs/index.php/eduakcja/article/view/80/50 (accessed 21.12.14).

34. Hamel, G. and Valikangas, L. (2003). The quest for resilience. In Harvard Business Review, 81(9), (pp. 52-63).

35. Hart, C. (2012). Factors associated with student persistence in an online program of study: A Review of the literature. In Journal of Interactive Online Learning, 11(1), (pp. 19-42).

36. Harvard Magazine (2012). Classroom in the Cloud. In John Harvard's Joumal, NovemberDecember, 2012. http://harvardmagazine.com/2012/11/classroom-in-the-cloud (accessed 21.12.14).

37. Herbst, S. (2013). What are the barriers to innovation? Forum discussion paper. In The Chronicle of Higher Education, October 4, (p. B45).

38. Hixon, E.; Buckenmeyer, J.; Barczyk, C.; Feldman, L.; Zamojski, H. (2012). Beyond the early adopters of online instruction: Motivating the reluctant majority. In Internet and Higher Education, 15(2), (pp. 102-107).

39. Hopkins, R. (2009). Resilience thinking. Resurgence, London. 
40. Hrabowski, F.A. (2011). Institutional change in higher education: Innovation and collaboration. Policy paper: Strategies to increase STEM achievement in higher education. McGraw-Hill Research Foundation.

https://www.mheonline.com/assets/pdf/STEM/WhitePapers/institutional_change_in_high er_education_white_paper.pdf (accessed 21.12.14).

41. Iwata, J. (2013). A new era of learning efficacy on a planet of smarter systems. In M. Barber \& S. Rizvi (eds.), Asking more: The path to efficacy, (pp. 23-27). Pearson, London, England.

42. Jaggars, S.S. (2011). Online learning: Does it help low-income and underprepared students. CCRC Working Paper No. 26. http://ccrc.tc.columbia.edu/media/k2/attachments/online-learninghelp-students.pdf (accessed 21.12.14).

43. Jaipal Jamani, K. and Figg, C. (2013). The TPACK-in-practice workshop approach: A shift from learning the tool to learning about technology-enhanced teaching. In the Proceedings of The International Conference on E-Learning, (pp. 215-223).

44. Johnson, L.; Adams Becker, S.; Cummins, M.; Freeman, A.; Ifenthaler, D.; Vardaxis, N. (2013). Technology outlook for Australian tertiary education 2013-2018: An NMC Horizon Project regional analysis. The New Media Consortium, Austin, TX.

45. Johnston, R.; Fitzgerald, L.; Markous, E.; Brignall, S. (2001). Target setting for evolutionary and revolutionary process change. In International Journal of Operations and Production Management, 21(11), (pp. 1387-1403).

46. Keohane, N.O. (2013). Higher education in the Twenty-First Century: Innovation, adaptation, preservation. In PS: Political Science and Politics, 46(1), (pp. 102-105).

47. Laurillard, D. (2012). Teaching as a Design Science: Building pedagogical patterns for learning and technology. New York and London: Routledge.

48. Lipson, K. (2013). Dealing with megaclasses in an online environment. Paper presented at the 59th ISI World Statistics, Hong Kong, China. http://www.statistics.gov.hk/wsc/IPS040-P3-S.pdf (accessed 21.12.14).

49. Liyanagunawardena, T.; Adams, A.; Williams, S. (2013). MOOCs: A systematic study of the published literature 2008-2012. In International Review of Research in Open \& Distance Learning, 14(3), (pp. 202-227).

50. Mackenzie, B. (2013). Critical success factors for public-private partnerships in entirely digital higher education. Paper presented at the Online Educa Berlin, December 4-6, 2013.

51. Mangan, K. (2013). Inside the flipped classroom. In The Chronicle of Higher Education, October 4, (p. B18).

52. McGonigal, J. (2011). Reality is Broken: Why games make us better and how they can change the world. Penguin Group, New York.

53. Miller, G.; Benke, M.; Chaloux, B.; Ragan, L.C.; Schroeder, R.; Smutz, W.; Swan, K. (2014). Leading the e-learning transformation of Higher Education: Meeting the challenges of technology and distance education. Stylus Publishing, Sterling, VA.

54. Morgan, J. (2013). Universities challenged: The impact of digital technology on teaching and learning. Universitas 21, An Educational Innovation Position Paper.

http://www.universitas21.com/RelatedFile/Download/494 (accessed 21.12.14).

55. Mulgan, G. (2013). Reality checks. In M. Barber \& S. Rizvi (eds.), Asking more: The path to efficacy, (pp. 17-22). Pearson, London. 
56. New Media Consortium (2013). NMC Horizon Report: 2014 Higher Education Preview. http://www.nmc.org/pdf/2014-horizon-he-preview.pdf (accessed 21.12.14).

57. Norman, D.A. and Verganti, R. (2014). Incremental and radical innovation: Design research vs. technology and meaning change. In Design Issues, 30(1), (pp. 78-96). doi:10.1162/DESI_a_00250

58. Olivier, B.; Yuan, L.; Millwood, R.; Kamtsiou, V. (2013). Adaptive Roadmapping. In F. Wild, P. Lefrere \& P. Scott (eds.), Advances in Technology Enhanced Learning. The Open University.

59. Pertusa-Ortega, E.M.; Molina-Azorín, J.F.; Claver-Cortés, E. (2010). Competitive strategy, structure and firm performance: A comparison of the resource-based view and the contingency approach. In Management Decision, 48(8), (pp. 1282-1303).

60. Pittard, V. (2004). Evidence for digitally enhanced learning policy. In Technology, Pedagogy and Education, 13(2), (pp. 181-193).

61. Richards, R.; O’Shea, J.; Connolly, M. (2004). Managing the concept of strategic change within a higher education institution: the role of strategic and scenario planning techniques. In Strategic Change, 13, (pp. 345-359).

62. Ritala, P. and Hurmelinna-Laukkanen, P. (2013). Incremental and Radical Innovation in Competition: The Role of Absorptive Capacity and Appropriability. In Journal of Product Innovation Management, 30(1), (pp. 154-169). doi:10.1111/j.1540-5885.2012.00956.x

63. Salaman, G. and Asch, D. (2003). Strategy and capability: Sustaining organizational change. Blackwell Publishing, Oxford.

64. Salmon, G. (2005). Flying not flapping: A strategic framework for e-learning and pedagogical innovation in higher education institutions. In ALT-J: Research in Learning Technology, 13(3), (pp. 201-218).

65. Salmon, G. (2011). E-moderating: The key to teaching and learning online, third ed. Routledge, New York.

66. Salmon, G. (2013a). E-tivities: The key to active online learning, second ed. Routledge, New York.

67. Salmon, G. (2013b). Public meets private. Online Educa Berlin. http://www.onlineeduca.com/OEB_Newsportal/public-meets-private/ (accessed 23.01.14).

68. Salmon, G. and Angood, R. (2013). Sleeping with the enemy. In British Journal of Educational Technology, 44, (pp. 916-925).

69. Salmon, G. and Wright, P. (2014). Transforming future teaching through 'Carpe Diem' learning design. In Education Sciences, 4(1), (pp. 52-63). Retrieved 14 January, 2014, from http://hdl.handle.net/1959.3/367751

70. Salmon, G.; Gregory, J.; Lokuge Dona, K.; Ross, B. (in press). Experiential online development for educators: The example of the Carpe Diem MOOC. In British Journal of Educational Technology.

71. Scharmer, O. (2009). Theory U: Leading from the future as it emerges. San Francisco: BerrettKochler.

72. Schneckenberg, D. (2009). Understanding the Real Barriers to Technology-Enhanced Innovation in Higher Education. In Educational Research, 51(4), (pp. 411-424).

73. Selingo, J. (2013). Presidents and professors largely agree on who should lead innovation. In The Chronicle of Higher Education, October 4, (p. B15). 
74. Simpson, O. (2012). Supporting students for success in online and distance education, third ed. Routledge: New York \& London.

75. Swinburne Online (2014). About us. http://www.swinburneonline.edu.au/about-us (accessed 21.12.14).

76. Tamim, R.M.; Bernard, R.M.; Borokhovski, E.; Abrami, P.C.; Schmid, R.F. (2011). What forty years of research says about the impact of technology on learning: A second-order metaanalysis and validation study. In Review of Educational Research, 81(1), (pp. 4-28). doi:10.3102/0034654310393361

77. Tham, C.M. and Werner, J.M. (2005). Designing and evaluating digitally enhanced learning in higher education: a review and recommendations. In Journal of Leadership and Organizational Studies, 11, (p. 15).

78. Watson, W.R.; Watson, S.L.; Reigeluthb, C.M. (2013). Education 3.0: Breaking the mold with technology. In Interactive Learning Environments, 21. doi:10.1080/10494820.2013.764322

79. Weller, M. and Anderson, T. (2013). Digital resilience in Higher Education. In European Journal of Open, Distance and E-Learning, 16(1).

http:/ / www.eurodl.org/index.php? $\mathrm{p}=$ archives\&year $=2013 \&$ halfyear $=1$ \&abstract $=559$ (accessed 15.01.14).

80. Westera, W. (2004). On strategies of educational innovation: between substitution and transformation. In Higher Education, 47, (pp. 501-517).

81. Wheeler, M. (2009). Developing the Media Zoo in second life. In British Journal of Educational Technology, 40(3), (pp. 427-443). doi:10.1111/j.1467-8535.2009.00942.x

82. Whitworth, A. (2012). Invisible Success: Problems with the grand technological innovation in higher education. In Computers \& Education, 59(1), (pp. 145-155).

83. Winslett, G. (2012). Resisting innovation talk in higher education teaching and learning. In Discourse: Studies in the Cultural Politics of Education, 35(3), (pp. 163-176). doi:10.1080/01596306.2012.745728

84. Zemsky, R. (2013). Checklist for change: Making American Higher Education a sustainable enterprise. Rutgers University Press, New Brunswick, NJ.

85. Zemsky, R. and Massy, W.F. (2004). Thwarted innovation: what happened to digitally enhanced learning and why. Final report for the weatherstation project of the Learning Alliance, University of Pennsylvania.

86. Zentel, P.; Bett, K.; Meiter, D.M.; Rinn, U.; Wedekind, J. (2004). A changing process at German universities - innovation through information and communication technologies? In Electronic Journal on digitally enhanced learning, 2(1), (pp. 237-246). 